\title{
Estudos sobre o processo criativo de Marcelo Grassmann: um desvio
}

\section{Rodrigo Henriques de Faria (IC)}

\section{Resumo}

O objetivo previsto para o segundo ano desta pesquisa foi o deslocamento da investigação histórico-biográfica e relacionada ao estudo dos materiais de desenho utilizados pelo artista Marcelo Grassmann, para as questões subjetivas presentes na elaboração da imagem. Dessa maneira o trabalho apresenta discussões sobre os acasos presentes na elaboração do desenho, sobre questões a respeito da expressividade na obra de arte, da percepção do espaço, entre outros aspectos.

Palavras Chave: Desenho - Gravura - Processo criativo

\section{Introdução}

Permanecemos investigando o desenho e as técnicas do artista entretanto com um olhar para sua atitude e as possíveis maneiras de se posicionar diante da produção pictórica. Ao longo da pesquisa procuramos entender os processos criativos de Marcelo Grassmann através das minhas próprias experiências e dúvidas a respeito do desenho. Entre as questões levantadas está a proposta de entender de que modo o olhar e a representação daquilo que se vê é influenciada pelo desenvolvimento cognitivo e emocional do individuo.

\section{Resultados e Discussão}

O embasamento teórico sobre o desenho é apresentado em três resenhas. A primeira discute os diferentes processos envolvidos na percepção e como os elementos da obra de arte se articulam e dialogam com o espectador. A segunda aborda a linguagem e os conteúdos presentes na produção artística desdobrando questões ligadas à experiência estética e à expressividade das formas da matéria gráfica. A terceira aborda essas mesmas questões com um viés filosófico. Por fim, a etapa teórica é concluída com um relato a respeito da influência dessas questões no cotidiano do atelier.

O desenvolvimento da prática consiste em quatro séries de desenhos onde as técnicas e as diferentes abordagens são descritas a partir de exemplos da produção do Grassmann.
Apresentamos ainda como parte dos resultados uma oficina de monotipia, que possibilitou levar ao público a experiência de um processo de criação em desenho.
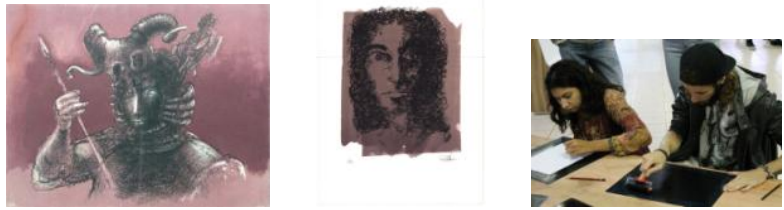

Figura 1. Desenho do Marcelo Grassmann

Figura 2. Desenho do pesquisador

Figura 3. Oficina de monotipia

\section{Conclusões}

A pesquisa desdobrou temas relevantes ao processo criativo do artista, que muitas vezes ficam restritas ao atelier e raramente chegam ao conhecimento público. Dessa forma o estudo revelou as preocupações e as questões que giram em torno do artista durante o exercício do seu trabalho, bem como as questões técnicas e existenciais presentes na concepção de uma obra artística.

\section{Agradecimentos}

Agradeço a professora Lygia Eluf por compartilhar seus conhecimentos e por acreditar na proposta deste trabalho. Ao Pibic/SAE Unicamp pelo financiamento dos estudos. Aos amigos e colegas.

\footnotetext{
OSTROWER, Fayga. Acasos e a criação artística. Rio de Janeiro: Editora Campus, 2000

${ }^{2}$ LAUDANNA, Mayra e KOSSOVITCH, Leon. Marcello Grassmann 1942-1955. São Paulo: Edusp, 2014
} 